\title{
Influence of nitrogen deficiency on photosynthesis and chloroplast ultrastructure of pepper plants
}

\author{
Snejana Doncheva, V. Vassileva, G. Ignatov, S. Pandev \\ Institute of Plant Physiology, Bulgarian Academy of Sciences, Sofia, Bulgaria \\ Ramdane Dris and Raina Niskanen \\ Department of Applied Biology, PO Box 27, FIN-00014 University of Helsinki, Finland, \\ e-mail: ramdane.dris@helsinki.fi
}

\begin{abstract}
Pepper plants (Capsicum annuum L. cv. Zlaten Medal) were grown on nutrient solution without nitrogen, and photosynthetic response of plants was examined by determination of leaf $\mathrm{CO}_{2}$ fixation and chlorophyll and carotenoid contents. The absence of nitrogen in the medium resulted in a decrease of the leaf area and of plant biomass accumulation, and in an increase of the root-shoot dry weight ratio. The photosynthetic activity and chlorophyll and carotenoid contents decreased significantly under nitrogen deprivation. Examination of nitrogen deficient leaves by transmission electron microscopy showed dramatic changes in chloroplast ultrastructure. The proportion of starch granules and plastoglobules in the stroma matrix was increased and internal membrane system was greatly reduced. It seems that nitrogen plays an important role in the formation of chloroplast structure and hence to the photosynthetic intensity and productivity of pepper plants.
\end{abstract}

Key words: Capsicum annuum, $\mathrm{CO}_{2}$ assimilation, leaf area, nitrogen deficiency, photosynthetic pigments, plastoglobules, starch

\section{Introduction}

The nitrogen supply is one of the major factors determining the growth of plants. As a constituent of chlorophyll molecule and carboxylating enzymes, nitrogen is essential for the maintenance of active photosynthesis and production of carbohydrates (Peoples et al. 1980). When nitrogen availability is low, the leaf cell number and volume (Lawlor et al. 1989), cell wall extensibility (Taylor et al. 1993) and photosynthesis (Kutik et al. 1995, Meinzer and Zhu 1998) are markedly reduced. Nitrogen deficiency decreases $\mathrm{CO}_{2}$ assimilation capacity (Terashima and Evans 1988) and the quantum yield of photosynthesis (Lawlor et al. 1987). It also affects PSII photochemistry, including the decrease in the quantum yield of PSII electron transport and the sufficiency of excitation energy capture by

\section{(C) Agricultural and Food Science in Finland Manuscript received August 2000}




\section{AGRICULTURAL AND FOOD SCIENCE IN FINLAND}

Doncheva, S. et al. Nitrogen deficiency, photosynthesis and chloroplasts of pepper plants

open PSII reaction centres (Verhoeven et al. 1997). At the ultrastructural level, the $\mathrm{N}$ deficiency reduces chloroplast size and the amount of thylakoids and increases the amount of nonnitrogenous substances such as starch and the size of plastoglobuli containing isoprenoid plastoquinone (Laza et al. 1993, Kutik et al. 1993, 1995). The aim of the present investigation was to study the effect of $\mathrm{N}$ deficiency on photosynthetic function and ultrastructure of mesophyll cell chloroplasts of pepper plants.

\section{Material and methods}

Five-day-old pepper seedlings (Capsicum annuum L. cv. Zlaten Medal) were grown hydroponically in naturally illuminated greenhouse with photoperiod of $16 \mathrm{~h}$ at $25 / 19^{\circ} \mathrm{C}$ day/night temperatures. The nutrient solution contained per litre of distilled water $0.944 \mathrm{~g} \mathrm{Ca}\left(\mathrm{NO}_{3}\right)_{2} .4 \mathrm{H}_{2} \mathrm{O}$; $0.738 \mathrm{~g} \mathrm{MgSO}_{4} .7 \mathrm{H}_{2} \mathrm{O} ; 0.816 \mathrm{~g} \mathrm{KH}_{2} \mathrm{PO}_{4} ; 0.170 \mathrm{~g}$ $\mathrm{NaNO}_{3}$ and micronutrients (Hoagland and Arnon 1938). Solution $\mathrm{pH}$ was maintained near 6.0 through the addition of $0.1 \mathrm{M} \mathrm{KOH}$. The plant material was divided into two experimental variants: (1) plants on full nutrient solution (control); (2) plants with nutrient solution lacking nitrogen. The nutrient solution was continuously aerated and changed twice in a week. Plants were harvested 30 days after planting. Twelve plants were used for each variant and three independent experiments were done. At harvest, leaf area and fresh weight were measured and different plant organs were weighed after drying at $60^{\circ} \mathrm{C}$ to give a constant weight.

The pigments of the photosynthetic apparatus (chlorophyll $a$ and $b$ and carotenoids) were extracted in 80\% acetone (Arnon 1949) and concentrations were determined spectrophotometrically using the extinction coefficients proposed by Mc Kinney (1941).

The rate of photosynthetic $\mathrm{CO}_{2}$ fixation was determined as described by Fedina et al. (1994). The leaf discs of $5 \mathrm{~mm}$ in diameter, taken from each variant after 30 day treatment, were kept in a closed chamber for short-term (20 min) exposition in the atmosphere containing ${ }^{14} \mathrm{CO}_{2}$ with 7.4 MBq ${ }^{14} \mathrm{C}$ under irradiation of $920 \mu \mathrm{mol} \mathrm{m}{ }^{-2}$ $\mathrm{s}^{-1}$ at $25^{\circ} \mathrm{C}$. The radioactivity of the samples was determined by scintillation counting. Each experiment was repeated three times. $\mathrm{CO}_{2}$ assimilation was calculated in $\mathrm{CO}_{2} \mathrm{mg} \mathrm{dm}^{-2} \mathrm{~h}^{-1}$.

Leaf portions (1-2 $\left.\mathrm{mm}^{2}\right)$ from the control and nitrogen deficient plants were fixed with $5 \%(\mathrm{w} /$ v) glutaraldehyde in Na-cacodylate buffer $(\mathrm{pH}$ 7.2) at $4^{\circ} \mathrm{C}$ for $3 \mathrm{~h}$, and postfixed with $1.3 \%$ $\mathrm{OsO}_{4}(\mathrm{w} / \mathrm{v})$ in the same buffer. Then, the samples were buffer-washed and dehydrated through a graded ethanol series (25-100\%, v/v), ethanolpropylene oxide $(1: 1, \mathrm{v} / \mathrm{v})$, propylene oxide and propylene oxide-Durcupan ACM $(1: 1, \mathrm{v} / \mathrm{v})$, and embedded in Durcupan ACM (Fluka AG, Buchs, Switzerland). Ultrathin sections were stained with uranyl acetate and lead citrate (Reynolds 1963) and examined with a transmission electron microscope (JEM $100 \mathrm{~B}$, JEOL, Japan) at $80 \mathrm{kV}$.

A morphometric analysis of the chloroplast structures was performed for the estimation of chloroplast area and length, starch inclusions, plastoglobules and number of granal thylakoids. From 10 randomly chosen ultrathin sections of each treatment, 10-18 fields over the image screen were measured with a semiautomatic image analyzer (Morphomat 10, Zeiss, Oberkochen, Germany).

\section{Results and discussion}

In comparison with the control, the total dry weight and the total and specific leaf area decreased and the root to shoot dry weight ratio increased significantly in the nitrogen deficient pepper plants (Table 1). Probably, the enhanced root growth and retarded shoot growth in N-deficient plants is related to a high cytokinin/ABA ratio in the roots and to a low ratio in the shoots (Mardanov et al. 1998). The acceleration of root 


\section{AGRICULTURAL AND FOOD SCIENCE IN FINLAND}

Vol. 10 (2001): 59-64.

Table 1. Biomass accumulation, leaf area and specific leaf area (total leaf area/fresh weight of leaves), pigment contents, the rate of photosynthetic assimilation of ${ }^{14} \mathrm{CO}_{2}$ and the main parameters of chloroplast structure in leaves of pepper plants grown with (control) and without $(-\mathrm{N})$ nitrogen supply (means and standard deviations).

\begin{tabular}{llll}
\hline & Control & $-\mathrm{N}$ & $\begin{array}{l}\text { Significance } \\
\text { of difference }\end{array}$ \\
\hline Dry weight $(\mathrm{g} / \mathrm{plant})$ & $6.62 \pm 0.40 \mathrm{a}$ & $0.79 \pm 0.03 \mathrm{~b}$ & $* *$ \\
Root dry weight/shoot dry weight & $0.23 \mathrm{~b}$ & $0.59 \mathrm{a}$ & $* *$ \\
Leaf area $\left(\mathrm{dm}^{2} / \mathrm{plant}\right)$ & $605 \pm 31 \mathrm{a}$ & $65 \pm 5 \mathrm{~b}$ & $* *$ \\
Specific leaf area $\left(\mathrm{dm}^{2} / \mathrm{g}\right.$ fresh weight) & $32.7 \pm 1.1 \mathrm{a}$ & $30.2 \pm 0.9 \mathrm{~b}$ & $*$ \\
Chlorophyll $a(\mathrm{mg} / \mathrm{g}$ fresh weight) & $0.97 \pm 0.05 \mathrm{a}$ & $0.21 \pm 0.01 \mathrm{~b}$ & $* *$ \\
Chlorophyll $b(\mathrm{mg} / \mathrm{g}$ fresh weight $)$ & $0.51 \pm 0.03 \mathrm{a}$ & $0.14 \pm 0.02 \mathrm{~b}$ & $* *$ \\
Chlorophyll $\mathrm{a} / \mathrm{b}$ & $1.89 \mathrm{a}$ & $1.49 \mathrm{~b}$ & $*$ \\
Carotenoids $(\mathrm{mg} / \mathrm{g}$ fresh weight $)$ & $0.26 \pm 0.01 \mathrm{a}$ & $0.18 \pm 0.02 \mathrm{~b}$ & $* *$ \\
Rate of $\mathrm{CO}_{2}$ assimilation $\left(\mathrm{CO}_{2} \mathrm{mg} / \mathrm{dm}^{2} \mathrm{~h}\right)$ & $20.3 \pm 1.3 \mathrm{a}$ & $2.3 \pm 0.1 \mathrm{~b}$ & $* *$ \\
Chloroplast area $\left(\mu \mathrm{m}^{2}\right)$ & $10.7 \pm 0.8 \mathrm{~b}$ & $12.9 \pm 0.8 \mathrm{a}$ & $*$ \\
Chloroplast length $(\mu \mathrm{m})$ & $6.4 \pm 0.5 \mathrm{a}$ & $4.3 \pm 0.3 \mathrm{~b}$ & $*$ \\
Number of grana per chloroplast & $19.0 \pm 1.0 \mathrm{a}$ & $3.6 \pm 0.2 \mathrm{~b}$ & $* *$ \\
Number of thylakoids per granum & $11.0 \pm 0.8 \mathrm{a}$ & $4.0 \pm 0.3 \mathrm{~b}$ & $* *$ \\
Number of starch inclusions & $1.7 \pm 0.2 \mathrm{~b}$ & $4.0 \pm 0.3 \mathrm{a}$ & $* *$ \\
Starch inclusions $\%$ of chloroplast area & $11.0 \mathrm{~b}$ & $68.0 \mathrm{a}$ & $* *$ \\
Plastoglobules $\%$ of chloroplast area & $5.6 \mathrm{~b}$ & $6.7 \mathrm{a}$ & $*$ \\
\hline
\end{tabular}

** significant at $1 \%$ level, according to ANOVA

* significant at $5 \%$ level, according to ANOVAs

growth provides an increasing demand for assimilates and changes the source-sink system in $\mathrm{N}$-deficient plants in favour of the roots (Marschner et al. 1996). Total chlorophyll and carotenoid contents, the chlorophyll a/b ratio and the photosynthetic efficiency, indicated by the rate of $\mathrm{CO}_{2}$ assimilation, were significantly lower in leaves of nitrogen deficient plants compared with the control (Table 1). These results are in accordance with other studies reporting that $\mathrm{N}$ deficiency decreases the chlorophyll content per unit area (Lichtenthaler 1973), the chlorophyll and carotenoid formation (Sundqvist et al. 1980) and the rate of net photosynthesis (Lawlor et al. 1989).

At TEM, the chloroplasts of leaves of control plants appeared elongated in shape and with the stroma containing some small starch grains and small dark plastoglobules (Fig. 1a). The system of thylakoids was organized into grana stacks and single intergranal thylakoids (Fig. 1b).
On the contrary, the chloroplasts of nitrogen deficient leaves were mostly more rounded and the stroma was filled with massive starch grains (Fig. 1c). Granal thylakoids were distorted and disordered with a lower stacking degree, and were pushed towards the periphery of the chloroplasts (Fig. 1d). Some loculi of the granal thylakoids were swollen (Fig. 1d). Morphometric analysis showed that the cross sectional area of the control plant chloroplasts was smaller, but the chloroplast length, the number of grana per chloroplast and the number of thylakoids per granum were higher with respect to N-deficient plant chloroplasts (Table 1). The proportion of stroma matrix of the chloroplasts cross section occupied by starch inclusions and plastoglobules was increased in nitrogen deficient plants (Table 1).

The formation of large starch inclusions in the nitrogen deficient chloroplasts can be caused by production of photosynthates in excess with respect to the sink capacity. Impaired export from 


\section{AGRICULTURAL AND FOOD SCIENCE IN FINLAND}

Doncheva, S. et al. Nitrogen deficiency, photosynthesis and chloroplasts of pepper plants
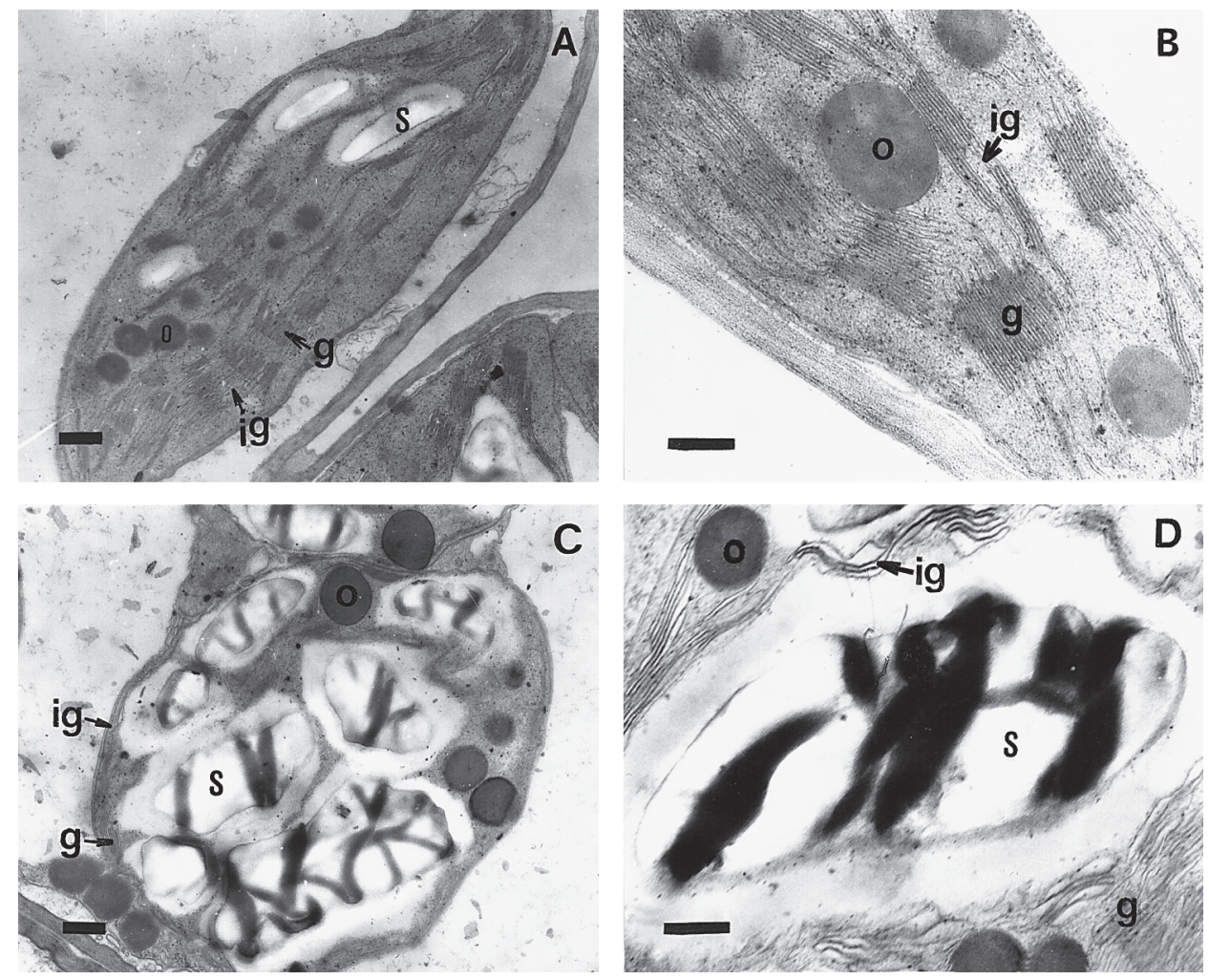

Fig. 1. Transmission electron micrographs of chloroplasts from leaves of pepper plants grown on nutrient solution: (A, B) with nitrogen (control); (C, D) without nitrogen. (A) Chloroplast from control leaf with well developed grana, intergranal thylakoids, some starch inclusions and plastoglobules. (B) Part of chloroplast from control leaf with grana and intergranal thylakoids. (C) Chloroplast from nitrogen deficient leaf with damaged grana, singly thylakoids, highly stained plastoglobules and large starch inclusions forcing the thylakoidal membranes to the periphery. (D) Part of chloroplast from nitrogen deficient leaf with large starch inclusions and incompletely stacked and swollen thylakoids. Note: (g) grana; (ig) intergranal thylakoids; (s) starch inclusions; (o) plastoglobules. Bars $=0.1 \mu \mathrm{m}$. (Photo: Snejana Doncheva).

the source leaves leads to sucrose accumulation and facilitates the flow of newly fixed carbon into starch by exerting an inhibitory role on enzymes synthesizing sucrose (Carmak et al. 1994).

The abundance of plastoglobuli in the nitrogen deficient plant chloroplast stroma has often corresponded to a minimum of thylakoid development (Tevini and Steinmüller 1985). Because plastoglobuli may serve as pools for storage of thylakoid constituents especially of lipids (Steinmüller and Tevini 1985), the increased volume of plastoglobules under nitrogen deficiency could mean a greater accumulation of lipids (Kutik et al. 1993).

Our results allow to suggest that chloroplast alterations upon nitrogen deficiency were developed as direct or indirect consequences of decreased chlorophyll and carotenoid contents. Normal thylakoid stacking could be prevented by low content of photosynthetic pigments (Yalovsky et al. 1992, Kuhlbrandt et al. 1994, Wrischer et al. 1998). A strong correlation has been found between $\mathrm{N}$ deficiency-induced reduction of photosynthesis and decline in ultrastruc- 


\title{
AGRICULTURAL AND FOOD SCIENCE IN FINLAND
}

\author{
Vol. 10 (2001): 59-64.
}

tural order (Laza et al. 1993). The reduction of $\mathrm{CO}_{2}$ fixation in nitrogen deficient leaves might also be due to the disruption of chloroplast structures by starch grains formed inside the organelles. Starch grains may decrease photosynthesis either by interfering with light transmission to photochemical centres or by increasing the resistance to $\mathrm{CO}_{2}$ diffusion (Neales and Incoll 1968).

In summary, the results demonstrate the importance of an adequate nitrogen nutrition for the formation of normal chloroplast structure and hence for the photosynthetic intensity and productivity of the pepper plants.

\section{References}

Arnon, D.I. 1949. Copper enzymes in isolated chloroplasts. Polyphenol oxidases in Beta vulgaris. Plant Physiology 24: 1-15.

Carmak, I., Hengeler, C. \& Marchner, H. 1994. Partitioning of shoot and root dry matter and carbohydrates in bean plants suffering from phosphorus, potassium and magnesium deficiency. Journal of Experimental Botany 45, 278: 1245-1250.

Fedina, I.S., Tsonev, T.D. \& Guleva, E.I. 1994. ABA as a modulator of the response of Pisum sativum to salt stress. Journal of Plant Physiology 143: 245-249.

Hoagland, D.R. \& Arnon, D.I. 1938. The water culture method for growing plants without soil. California Agricultural Experimental Station Circular 347: 1-39.

Kuhlbrandt, W., Wang, D.N. \& Fujiyoshi, Y. 1994. Atomic model of plant light-harvesting complex by electron crystallography. Nature 367: 614-621.

Kutik, J., Cincerova, A. \& Dvorak, M. 1993. Chloroplasts ultrastructural development during the ontogeny of the second leaf of wheat under nitrogen deficiency. Photosynthetica 28: 447-453.

- , Natr, L., Demmers-Derks, H.H. \& Lawlor, D.W. 1995. Chloroplast ultrastructure of sugar beet (Beta vulgaris L.) cultivated in normal and elevated $\mathrm{CO}$ concentrations with two contrasted nitrogen supplies. Journal of Experimental Botany 46, 293: 1797-1802.

Lawlor, D.W., Boyle, F.A., Young, A.T., Kendall, A.C. \& Keys, A.J. 1987. Nitrate nutrition and temperature effects on wheat: Soluble components of leaves and carbon fluxes to amino acids and sucrose. Journal of Experimental Botany 38: 1091-2103.

- , Kontturi, M. \& Young, A.T. 1989. Photosynthesis by flag leaves of wheat in relation to protein, ribulose bisphosphate carboxylase activity and nitrogen supply. Journal of Experimental Botany 40: 43-52.

Laza, R.C., Bergman, B. \& Vergara, B.S. 1993. Cultivar differences in growth and chloroplast ultrastructure in rice as affected by nitrogen. Journal of Experimental Botany 44: 1643-1648.

Lichtenthaler, H.K. 1973. Regulation der Lipochinonsynthese in Chloroplasten. Berichte der Deutschen Botanischen Gesselschaft 86: 313-329.

Mc Kinney, G. 1941. Absorption of light by chlorophyll solutions. Journal of Biology Chemistry 140: 315322.
Mardanov, A., Samedovam, A., Shirvany, T. \& Box, J.E. 1998. Root-shoot relationships in plant adaptation to nitrogen deficiency. Root demographics and their efficiencies in sustainable agriculture, grassland and forest ecosystems. Proceedings of the 5th Symposium of the International Society of Root Research, 14-18 July, 1996, Clemson University, South Carolina, USA. Developments in Plant and Soil Sciences, Vol. 28: 147-154.

Marschner, H., Kirkby, E.A. \& Cakmak, I. 1996. Effect of mineral nutritional status on shoot-root partitioning of photoassimilates and cycling of mineral nutrients. Journal of Experimental Botany 47: 1255-1263.

Meinzer, F.C. \& Zhu, J. 1998. Nitrogen stress reduces the efficiency of the $\mathrm{C}_{4} \mathrm{CO}_{2}$ concentrating system, and therefore quantum yield, in Saccharum (sugarcane) species. Journal of Experimental Botany 49: 1227-1234.

Neales, T.E. \& Incoll, L.D. 1968. The control of leaf photosynthesis by level of assimilate concentration in the leaf: review of the hypothesis. Botanical Review 34: 107-125.

Peoples, M.B., Beilharz, V.C., Waters, S.P., Simpson, R.G. \& Dalling, M.J. 1980. Nitrogen redistribution during grain growth in wheat (Triticum aestivum L.). II. Chloroplast senescence and the degradation of ribulose-1,5-bisphosphate carboxylase. Planta 149: 241-251.

Reynolds, E.S. 1963. The use of lead citrate at high $\mathrm{pH}$ as an electron opaque stain in electron microscopy. Journal of Cell Biology 17: 208-212.

Steinmüller, D. \&. Tevini, M. 1985. Composition and function of plastoglobuli. I. Isolation and purification from chloroplasts and chromoplasts. Planta 163: 201-207.

Sundqvist, C., Bjorn, L.O. \& Virgin, H.I. 1980. Factors in chloroplast differentiation. In: Reinert, J. (ed.). Results in cell differentiation. Vol. 10. Berlin, Heidelberg: Springer-Verlag. p. 202-224.

Taylor, G., Mc Donald, A.G.S., Stadenberg, I. \& FreerSmith, P.H. 1993. Nitrate supply and biophysics of leaf growth in Salix viminalis. Journal of Experimental Botany 44: 155-164.

Terashima, I. \& Evans, J.R. 1988. Effects of light and nitrogen nutrition on the organization of the photosynthetic apparatus in spinach. Plant Cell Physiolo- 


\title{
AGRICULTURAL AND FOOD SCIENCE IN FINLAND
}

Doncheva, S. et al. Nitrogen deficiency, photosynthesis and chloroplasts of pepper plants

gy 29: 143-155

Tevini, M. \& Steinmüller, D. 1985. Composition and function of plastoglobuli. II. Lipid composition of leaves and plastoglobuli during beech leaf senescence. Planta 163: 91-96.

Verhoeven, A.S., Demming-Adams, B. \& Adams, W.W. 1997. Enhanced employment of the xanthophyll cycle and thermal energy dissipation in spinash ex posed to high light and $\mathrm{N}$ stress. Plant Physiology 113: 817-824.
Wrischer, M., Ljubesic, N. \& Salopek, B. 1998. The role of carotenoids in the structural and functional stability of thylakoids in plastids of dark-grown spruce seedlings. Journal of Plant Physiology 153: 46-52. Yalovsky, S., Neseman, E., Schuster, G., Paulsen, H., Harel, E. \& Nechushtal, R. 1992. Accumulation of a light-harvesting chlorophyll a/b protein in the chloroplast grana lamellae. Journal of Biology Chemistry 267: 20689-20693.

\section{SELOSTUS}

\section{Typen puutteen vaikutus paprikan fotosynteesiin ja kloroplastien rakenteeseen}

\author{
Snejana Doncheva, V. Vassileva, G. Ignatov, S. Pandev, Ramdane Dris ja Raina Niskanen
}

Bulgarian tiedeakatemia ja Helsingin yliopisto

\begin{abstract}
Liuosviljelyssä kasvatetulla paprikalla (Capsicum аппиит L. cv. Zlaten Medal) tutkittiin typen puutteen vaikutusta biomassan tuotantoon, fotosynteesiin ja kloroplastien rakenteeseen. Ilman typpilannoitusta lehtipinta-ala pieneni, biomassan kertyminen väheni ja juuren kuivapainon suhde verson kuivapainoon suureni. Typen puute heikensi fotosynteesiä alentamalla hiilidioksidin sitoutumisnopeutta ja leh-
\end{abstract}

tien klorofylli- ja karotenoidipitoisuutta ja aiheutti kloroplasteissa tärkkelysjyvästen ja plastoglobulien osuuden suurenemista sisäisen membraanirakenteen kustannuksella. Tulokset osoittavat, että kloroplastien rakenteen normaali muodostuminen, fotosynteesin tehokkuus ja paprikan sadon tuotto ovat riippuvaisia riittävästä typen saannista. 